\title{
ГИДРОТЕРМАЛЬНЫЙ СЕПИОЛИТ ИЗ КОРЫ ВЫВЕТРИВАНИЯ КРИСТАЛЛИЧЕСКОГО ФУНДАМЕНТА ЭСТОНИИ
}

В ходе рентгенографического исследования глинистых минералов коры выветривания кристаллического фундамента Әстонии в профиле скв. Ульясте № 45п (Северо-Восточная Эстония) был обнаружен сепиолит (Кууспалу и др., 1971). Это первая находка сепиолита в горных породах Эстонии. Сепиолит определен в двух образцах; в обонх случаях предполагается его гидротермальное происхождение.

В первом образце (обр. № 45-85, гл. 164,4 м) мономинеральный сепиолит встречен в выветрелом и гидротермально измененном форстеритовом мраморе. В неизмененном виде форстеритовые мраморы Ульястеского комплекса слагаются из форстерита и кальцита с примесью диопсида, пирротина, графита и флогопита, а также развивающегося по форстериту серпентина (Вахер и др., 1964). При выветривании магнезиальные силикаты разлагаются, кальцит замещается доломитом, обычно желтоватым или розоватым, пирротин - пиритом, марказитом и окислами-гидроокислами железа. В результате выветривания таким образом возникает пестроцветная доломитовая порода, характерная для всех скважин Ульястеской группы. В скв. № 45п на гипергенные процессы наложены низкотемпературные гидротермалыные изменения. Они выражаются главным образом в появлении полиметаллической галенит-сфалеритовой минерализации (Вахер и др., 1964), но также и в дедоломитизации карбонатной породы. Пестроцветная доломитовая порода сохранилась лишь пятнами. По ней развивается водяно-прозрачный или желтоватый кальцит, слагающий жило- или гнездообразные агрегаты, более крупнозернистые по сравнению с исходной доломитовой породой. К участкам новообразованного кальцита приурочены редкие свежие вкрапленники пирита, галенита и сфалерита и гнезда сепиолита. Сепиолит образует белую ватообразную, спутанно-волокнистую массу, которая тонким слоем обволакивает стенки пустот диаметром 0,5-3,0 см. Как правило, сепиолит встречается в виде нароста на кристаллах кальцита, причем поверхность последних заметно растворена. В сепиолитовых агрегатах нередко встречаются мелкие кристаллики марказита.

В иммерсионном препарате сепиолит наблюдается в виде спутаннотонковолокнистых агрегатов. Волокна или, что более вероятно, пучки волокон дают в скрещенных николях низкие серые цвета интерференции. Погасание прямое относительно удлинения; удлинение положительное; показатели преломления $\mathrm{Np}^{\prime} \simeq 1,485$ и $\mathrm{Ng}^{\prime} \simeq 1,503$. 
Описанный сепиолит образовался, по всей вероятности, в результате кристаллизации богатых магнием растворов, освободившихся при разложении доломита и магнезиальных силикатов в гидротермальных условиях.

Во втором образце (обр. № 45$144^{\text {A }}$, гл. 211, 9 м) сепиолит выступает в качестве материала заполнения трещины в свежих кварцитах. Макроскопически материал этот состоит из двух тонких мощностью

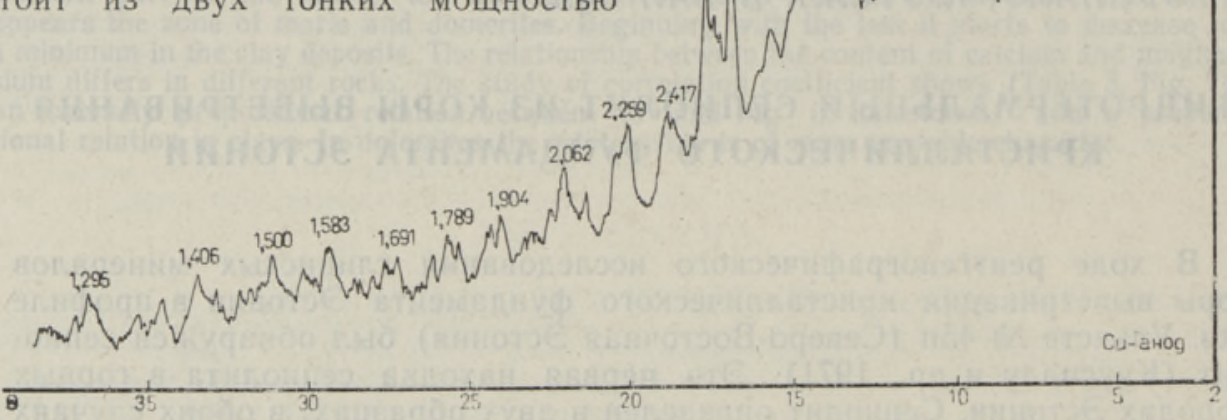

Рис. 1. Дифрактограмма сепиолита. Обр. № 45-85, скв. Ульясте № 45п, гл. 164,4 м.

около 0,2 мм слоев землистых веществ белого и зеленовато-черного цвета. Согласно дифрактометрическому определению сепиолит здесь присутствует в смеси с магнезиальным монтмориллонитом. Генезис сепиолита в данном случае надежно не устанавливается. Однако учитывая жильный характер залегания сепиолита, можно и здесь предполагать его гидротермальное происхождение.

Рентгеновскими методами сепиолит впервые охарактеризован Г. Мижоном (Migeon, 1936). Более детальные рентгеновские исследования структуры сепиолита проведены А. Прейзингером (Preisinger, 1959) и Г. В. Бриндли (Brindley, 1959).

При определении сепиолита из коры выветривания кристаллического фундамента Эстонии для сравнения мы использовали данные по дифракции рентгеновских лучей, опубликованные Г. В. Бриндли (Brindley, 1959).

Рентгенографические исследования сепиолита проводились в кабинете минералогии ТГУ на дифрактометрах УРС-50 ИМ и ДРОН-1 и дополнительно порошковым методом с рентгеновскими камерами РКД57,3 мм и РКУ-114,6 м.. Выяснилось, что изученный сепиолит можно отнести к хорошо окристаллизованной разности, о чем свидетельствуют большое количество и резкость дифракционных линий на рентгенограммах при относительно слабом фоне.

Дифрактограмма сепиолита приведена на рис. 1. Поскольку исследуемый сепиолит находился в породе в тесном контакте с кальцитом и его механическая сепарация под бинокуляром была затруднена, то для удаления кальцита проба была предварительно обработана $3 \%$-ной $\mathrm{HCl}$. Результаты показывают, что такая кислотная обработка не нарушила структуры сепиолита. На дифрактограмме видно множество рефлексов с асимметричными пиками. Обусловлено это, по-видимому, частым наложением друг на друга нескольких рефлексов, незначительно отличаю- 


\section{Рентгеновская характеристика сепиолита}

Данные порошковых рентгенограмм, по Г. В. Бриндли (Brindley, 1959).

\begin{tabular}{c|c|c|c}
\hline $\mathrm{hkl}$ & $\begin{array}{c}d(\AA) \text { рас- } \\
\text { четное }\end{array}$ & $I$ & $\begin{array}{c}d(\AA) \text { наб- } \\
\text { людаемое }\end{array}$ \\
\hline 1 & 2 & 3 & 4 \\
\hline
\end{tabular}

13,48

020
110

130

200

040

220

001

150

021

111

240

060

310

131

201

041

330

221

260

170

151

241

350

061

311

400

080

420

331

261

171

440

280

370

190

351

401

081

241

460

$0,10,0$

510

002

441

281

530

022

112

371

191

$2,10,0$

390

132

202

042
12,07

7,482

6,750 )

6,742 \}

6,036

5,255

5,008

4,896

4,818

4,780

4,495

4,438

4,301

4,146

4,145

4,023

3,964

3,741

3,705

3,626

3,532

3,455

3,416

3,391

3,375

3,370

3,274

3,195

3,048

3,028

3,018

3,016

2,928

2,925

2,887

2,840

2,837

2,778

2,699

2,697 )

2,687 \}

2,627

$2,618\}$

2,617 J

2,586

2.580

2,567

2,557

2,556

2,505

2,495

2,479

2,448 )

$2,448\}$
10

5

12,05

6,73

10

12,05

7,50

6,75

12,05

2

5,01

7

5,0

25

4,498

4,306

4,022

3,750

3,533

12

30

30

3,533

30

12

4

2,932

3,366

3,196

3,050

6
2

3,19

3,05

3,35

3,19

3,058

2,885

5 Ш

2,832

2,771

20

2,691

4

2,697

NR

55
3

2,631

2,617

2,586

2,560

9

2,580

2,600

2,564

2,683

2,629

2,479

2,449 


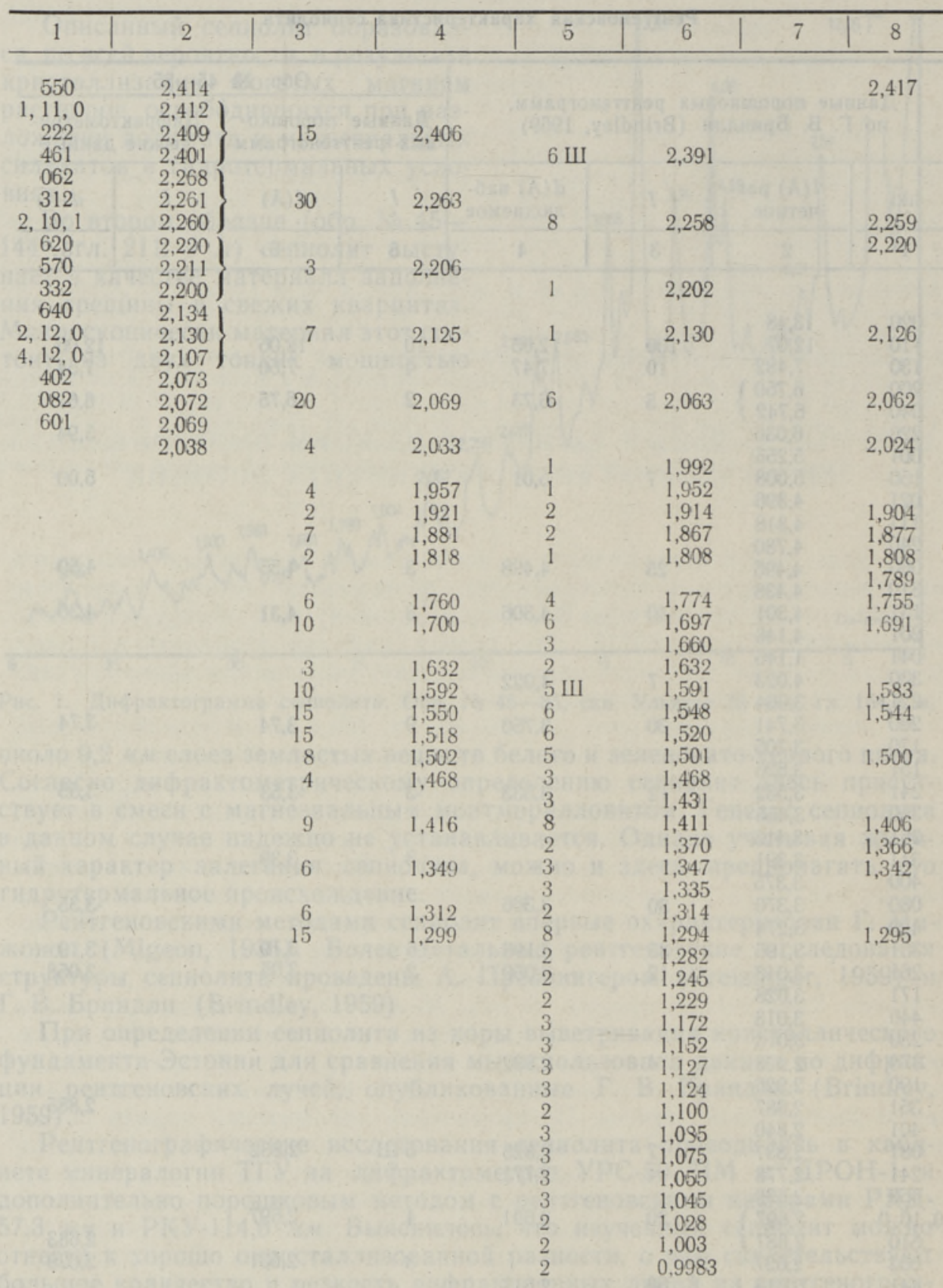

щихся между собой по углу $\Theta$. Полная информация о рефлексах сепиолита по Г. В. Бриндли и сравнение их с нашими данными приведены в таблице. Среди них присутствуют некоторые слабые рефлексы, принадлежащие не сепиолиту, а примесному марказиту.

Электронно-микроскопические исследования сепиолита проводились на кафедре экспериментальной физики ТГУ при содействии И. Тигане. Были использованы методы реплик и суспензии. Препарат исследовался под электронным микроскопом ЭМ-5 при увеличении до 20000 раз. 
Наблюдения показали, что исследуемый сепиолит имеет волокнистое строение (рис. $2, a, 6)$. Нередко волокна образуют пучковидные агрегаты длиной до 100 мкм и более (рис. 2,6$)$, отождествляемые по характерным формам также под поляризационным микроскопом. Диаметр отдельных волокон сепиолита колеблется от 0,03 до 0,1 мкм. В агрегатах сепиолита иногда попадаются хорошо выраженные ромбоэдрические спайные обломки и кристаллики кальцита (рис. $2, a)$.

В заключение нужно подчеркнуть, что локальное образование сепиолита - это частное проявление гидротермальных изменений, сопровождающих полиметаллическую минерализацию пород Эстонии. Поэтому очевидна необходимость дальнейшего углубленного исследования этих еще слабо изученных явлений, в том числе превращений глинистых минералов.

\section{Л И ТЕ Р А Т У Р А}

В ах ер Р. М., Ку успалу Т. И., Пу ур а В. А., Эри с а лу Э. К. 1964. О геологическом положении сульфидных рудопроявлений в районе Ульясте. В сб.: Литология палеозойских отложений Эстонин. Таллин.

Ку усп алу Т., В ан а м б В., У тсал К. 1971. О минералогии коры выветривания кристаллического фундамента Эстонии. Уч. зап. Тартуск. гос. ун-та, 286. Тр. по геол., VI.

B rind le y G. W. 1959. X-ray and electron diffraction data for sepiolite. Am. Mineral., 44, No. $5-6$.

Mig e on G. 1936. Contribution à l'étude de la définition des sépiolites. Bull. Soc. Fr. Min., 59.

Preis inger A. 1959. X-ray study of the structure of sepiolite, clays and clay minerals. Proc. 6th nation, confer. clays and clay minerals.

Тартуский государственный университет

Поступила в редакцию 11/I 1973

T. KUUSPALU, K. UTSAL, V. VANAMB

\section{HUDROTERMAALNE SEPIOLIIT EESTI ALUSKORRA MURENEMISKOORIKUST}

Kirjeldatakse sepioliidi esmasleidu Eesti kivimites. Kõnesolev sepioliit esineb kiuliste kogumikena Uljaste 45 puursüdamiku murenenud ja hüdrotermaalselt muutunud marmoris leiduvates väikestes tühikuis. Mineraalide assotsiatsioonid ja mineraalidevahelised suhted viitavad sepioliidi hüdrotermaalsele tekkele. Antakse sepioliidi lühike optiline, röntgenomeetriline ja elektronmikroskoopiline iseloomustus.

\section{T. KUUSPALU, K. UTSAL, V. VANAMB}

\section{ON THE HYDROTHERMAL SEPIOLITE FROM THE CRUST OF WEATHERING OF THE ESTONIAN CRYSTALLINE BASEMENT}

The first find of sepiolite in the Estonian country rocks is described. Sepiolite occurs as felted masses filling small cavities in weathered and hydrothermally changed forsteritebearing marble in drill core Uljaste No. 45, NE Estonia. The mineral associations and relationship of main minerals suggest a low-temperature hydrothermal origin of this sepiolite. A short review of the sepiolite is given on the basis of mega- and microscopic observations, and of X-ray and electron microscopy methods. 